\title{
Hiperspektral Vejetasyon İndeksleri Kullanarak Otlaklarda Kanopi Düzeyinde Klorofil İçeriğinin Tahmin Edilmesi*
}

\author{
Estimating Grassland Chlorophyll Content at Canopy Scales Using Hyperspectral \\ Vegetation Indices
}

\author{
Ahmet KARAKOÇ ${ }^{1}$ (D), Murat KARABULUT² (D) \\ ${ }^{1}$ Dr. Öğr. Üyesi, Osmaniye Korkut Ata Üniversitesi, Kadirli Sosyal ve Beşeri Bilimler Fakültesi, Coğrafya Bölümü, Osmaniye, Türkiye \\ ${ }^{2}$ Prof. Dr., Kahramanmaraş Sütçü İmam Üniversitesi, Fen-Edebiyat Fakültesi, Coğrafya Bölümü, Kahramanmaraş, Türkiye
}

ORCID: A.K. 0000-0003-1663-3323; M. K. 0000-0002-1456-6908

\section{Öz}

Bu çalışma, farklı ekolojik koşullara sahip otlaklarda, kanopi düzeyinde klorofil içeriğini hiperspektral vejetasyon indeksleri kullanarak tahmin etmeyi hedeflemiştir. Bunun için 500 m, 1200 m ve 1400 m olmak üzere üç farklı yükseltiye sahip otlak sahada, vejetasyonundaki klorofil içeriği verileri ile spektral verileri kanopi düzeyinde toplanmıştır. Bu işlemler 50X50 cmlik kuadratlar içerisinde ve 213 farklı noktada gerçekleştirilmiştir. Veri toplama metodu olarak amaçlı örneklem ve transekt yöntemleri tercih edilmiştir. Toplanan veriler önce elde edildikleri yükselti basamağına göre (saha-temelli) daha sonra da içerdiği klorofil miktarına göre (miktar-temelli) iki kategoriye ayrılmış ve değerlendirmeler bu kategoriler üzerinden yapılmıştır. Analizler için önce spektral eğriler yorumlanmış, daha sonra da bu verilerden hiperspektral vejetasyon indeksleri üretilmiştir. Vejetasyon indekslerinin klorofil içeriğindeki varyasyonları açıklama gücünü modellemek için ise doğrusal, üstel, logaritmik ve üs fonksiyon modelleri kullanarak regresyon analizleri yapılmıştır. Bulgular; tüm verilerin değerlendirildiği heterojen veri setinde $\% 85$ 'in üzerinde, çalışma sahasının yükseltisinde göre yapılan analizlerde (saha-temelli) ise \%90'ın üzerinde bir açıklama gücüne ulaşıldığını göstermiştir. Bu sahalarda, vejetasyondaki klorofil miktarı arttıkça modellerin gücünün belirgin bir şekilde azaldığı da ortaya konulmuştur. Bir başka dikkat çekici bulgu farklı çalışma alanlarından toplanarak benzer klorofil içeriklerine sahip örneklemler kullanılarak oluşturulan veri tabanında (miktar-temelli) açıklama gücünün belirgin bir biçimde düşmesi olmuştur.

Anahtar kelimeler: Hiperspektral uzaktan algılama, Vejetasyon indeksleri, Klorofil içeriği

\section{ABSTRACT}

This study aims to estimate the chlorophyll content at the canopy level using the hyperspectral vegetation indices in grasslands with different ecological conditions. For this purpose, all data were collected from three different elevation steps of $\sim 500 \mathrm{~m}, \sim 1200 \mathrm{~m}$, and $\sim 1400 \mathrm{~m}$. The operations were performed in $50 \times 50 \mathrm{~cm}$ quadrates at 213 different locations at the canopy level. Purposeful sampling and transect methods were preferred as the data collection methods. The database was divided into two categories according to the elevation step they were collected (field-based) and the amount of chlorophyll content (quantity-based). Assessments were then made in these two categories and their classes. In the analyses, the spectral curves were interpreted, and the hyperspectral vegetation indices were calculated from the aforementioned databases. Regression analyses were used to model the performances of the vegetation indices and explain the chlorophyll content variations. For this, linear, exponential, logarithmic, and power function models were employed. The results show an explanation power of over $85 \%$ in the data set containing all the data and over $90 \%$ in the field-based data set. In contrast, the power of the models significantly decreased as the chlorophyll content increased.

Keywords: Hyperspectral remote sensing, Vegetation indices, Chlorophyll content

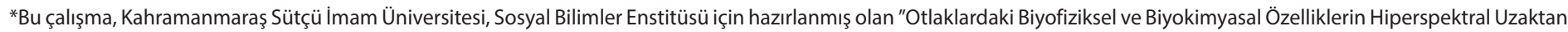

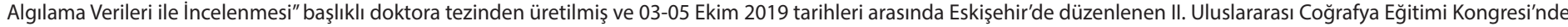
(UCEK-2019) sözlü bildiri (özet) olarak sunulmuştur.

Başvuru/Submitted: 20.01.2020 • Revizyon Talebi/Revision Requested: 11.05.2021 • Son Revizyon/Last Revision Received: 14.05.2021 • Kabul/Accepted: 25.10 .2021

Sorumlu yazar/Corresponding author: Ahmet KARAKOÇ / ahmetkarakocc@gmail.com

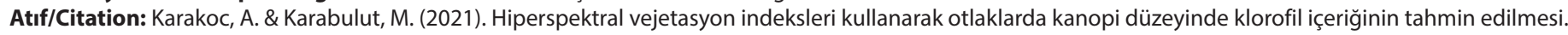
Cografya Dergisi, 43, 77-91. https://doi.org/10.26650/JGEOG2021-865289 


\section{EXTENDED ABSTRACT}

The biochemical properties of vegetation are directly related to photosynthetic production and how healthy a plant is. The chlorophyll content in plants is an indirect, but essential indicator of plant stress. The chlorophyll concentration gives indirect information about the plant's nutritional status. Therefore, plant stress research is one of the most popular topics in grassland vegetation studies. Various methods can be used to determine the chlorophyll content in the canopy scale. The most common methods are (1) the extraction of the leaf level chlorophyll as $\mu \mathrm{g} / \mathrm{cm}^{2}$ using acetone and sodium bicarbonate and its conversion to $\mathrm{g} / \mathrm{m}^{2}$ and scaling to the canopy level, (2) the conversion of measurements to the canopy level using hand-held chlorophyll meters that measure scaling at the leaf level, and (3) the direct measurement of the relative chlorophyll (chlorophyll index) at the canopy level using laser chlorophyll meters. Each method has certain advantages and disadvantages. Portable chlorophyll meters provide significant advantages in large areas and quick measurements.

The study was performed in Kahramanmaraş, which is located in the transition zone of the Mediterranean and Iran-Turan flora regions. Considering the different ecological conditions occurring in different elevation steps, the study was conducted in three different elevation steps of $\sim 500 \mathrm{~m}, \sim 1200 \mathrm{~m}$, and $\sim 1400 \mathrm{~m}$. In the first year of the data collection process, 63 samples (i.e., 21 from each field) were obtained. In the second year, 50 more samples were obtained from each field, and 213 samples were collected. All data collection procedures were performed during the peak periods of the vegetation activity in 2016 and 2017 considering the ecological character of each study site. Purposeful sampling and transect methods were preferred as the data collection methods. In the transect method, two 125 $\mathrm{m}$ transects were determined in the study areas, and the data were collected from $50 \times 50 \mathrm{~cm}$ quadrates placed in every $5 \mathrm{~m}$ interval.

The chlorophyll content data were obtained with a laser chlorophyll meter, while the spectral data were obtained with a hand-held spectroradiometer. The collected data were first evaluated altogether, then divided into two categories according to the elevation of the area from which they were obtained (field-based) and the amount of chlorophyll contained (quantity-based). Evaluations on these categories were then made. For analysis, descriptive statistics were first evaluated. Normality tests were then applied. For the next step, ratio-based hyperspectral vegetation indices were calculated from the hyperspectral data, and chlorophyll content variations were explained with these indices. Regression analysis was used for this explanation. Linear, exponential, logarithmic, and exponent function models were employed as the model functions.

The results showed an explanation power of over $85 \%$ in the data set containing all data using Simple Ratio (SR) (560,810) indices with the power model function. The field-based analysis presented 93\% with SR $(550,800)$ for $500 \mathrm{~m}, 90 \%$ with SR (710,750) at 1200 $\mathrm{m}$, and $72 \%$ with NDVI $(680,710,750)$ at $1400 \mathrm{~m}$. In contrast, the power of the models significantly decreased as the chlorophyll content increased. Another remarkable finding was that the explanatory power significantly decreased in the quantity-based database created with the samples having similar chlorophyll contents, albeit being collected from different study areas. In the quantity-based analysis, an explanation power of $78 \%$ was achieved in the data set with the low chlorophyll content, while $64 \%$ was acquired in the data set with the high chlorophyll content. This indicated that the saturation effect became prominent in the high chlorophyll content. By contrast, the collected samples produced more meaningful information within the unique field pattern, and the plant-light relationship may differ, despite the similar values of the features taken from different fields. 


\section{GİRIŞ}

Vejetasyonun biyokimyasal özellikleri, fotosentetik üretimle ve dolayısıyla da bitkinin ne kadar sağlıklı olduğu ile doğrudan ilişkilidir. Örneğin; vejetasyon kanopisindeki klorofil (Chl) konsantrasyonu, karotenoid (Cars), nitrojen $(N)$ ve fosfor $(P)$ gibi biyokimyasal değişkenler besin döngüsü (nutrient cycling), net birincil üretim (net primary production), fotosentez yeteneği (photosynthetic capability) ve ölü madde ayrışması (litter decomposition) gibi birçok fizyolojik süreci kontrol eder (He ve Mui, 2010: 11073; Li vd., 2014; 21123).

Bitkilerdeki klorofil içeriğinin bitki stresinin dolaylı fakat temel göstergelerinden biri sayılması (Carter ve Knapp, 2001), otlak vejetasyonu çalışmalarında bitki stresi araştırmalarının oldukça popüler olmasını sağlar. Örneğin, strese bağlı değişen klorofil konsantrasyonu ile kırmızı kenar (red-edge) pozisyonu (Curran vd., 1990) ve yaprak alan indeksi (LAI/Leaf area index) (Darvishzadeh vd., 2008) ilişkisinin değerlendirilmesi bu kapsamdaki konu başlıklarından bazılarıdır. Literatürde klorofil içeriği araştırmalarının yoğun ilgi görmesinin bir diğer nedeni de yapraktaki nitrojenin büyük çoğunluğunun klorofille birlikte bulunuyor oluşudur. Böylece vejetasyondaki klorofil konsantrasyonu bitkilerin besin durumu ile ilgili de dolaylı bilgiler verir (Gitelson vd., 2003: 272).

Kanopi ölçeğinde klorofil miktarının belirlenebilmesi için birçok farklı yöntem bulunmaktadır. Bunlardan en yaygın olanları; (1) aseton ve sodyum bikarbonat kullanılarak yaprak düzeyindeki klorofilin $\mu \mathrm{g} / \mathrm{cm}^{2}$ şeklinde çıkartılması ve daha sonra $\mathrm{g} / \mathrm{m}^{2}$ şekline dönüştürülerek kanopi düzeyine ölçeklendirilmesi (Wong ve He, 2013), (2) yaprak düzeyinde ölçüm yapan el tipi (handheld) klorofilmetreler kullanılarak ölçümlerin kanopi düzeyine ölçeklendirilmesi (Darvishzadeh vd., 2008) ve (3) lazerli klorofilmetreler kullanarak doğrudan kanopi düzeyindeki göreceli klorofilin (klorofil indeksi) ölçülmesi şeklindedir (Geng, 2013). Her bir yöntemin belli düzeyde avantaj ve dezavantajları vardır. Örneğin; aseton ve sodyum bikarbonat kullanılarak yapılan ölçüm, maliyetli ve uzun laboratuvar analizleri gerektiren ancak yüksek doğrulukta sonuçlar üreten bir yöntemdir. Bu çalışmada kullanılacak olan kanopi düzeyinde ölçüm yapan lazerli klorofilmetreler ise hızlı ve geniş alanlarda ölçüm yapabilmesi açısından önemli avantajlar sağlar (Mangiafico ve Guillard, 2005). Ancak hangi yöntemle yapılırsa yapılsın temel hedef ölçülen klorofil miktarı ile ikinci bir değişken(ler) (örneğin; çevresel faktörler, biyofiziksel özellikler, bitkilerin spektral davranışı) arasındaki ilişkilerin ortaya konulmasıdır.
Çok geniş (tek bantl1/ pankromatik) ve geniş (çok bantl1/ multispektral) spektral aralıklardan oluşan verilerle kıyaslandığında dar (yüzlerce bantlı) spektral aralıklardan oluşan hiperspektral uzaktan algılama verileri bitkilerin biyokimyasal özellikleri hakkında bilgi edinmek için çok daha avantajlı veri kaynaklarıdır. Canlı yaprağın spektral davranışını kontrol eden klorofil $(c h l a+b)$ hem spektrumun görünen 1 şı bölümünde hem de yakın kızılötesi (NIR) bölgede çok etkin bir role sahiptir (Karabulut, 2019: 113). Buradan hareketle dar ve birbirine komşu olan spektral aralıkların analizi ve bu bantların kombinasyonları ile oluşturalan hiperspektral vejetasyon indeksleri 1şık-klorofil ilişkisinin analizinde çok güçlü bir araç olarak karşımıza çıkar. Örneğin Tong ve He (2014), klorofil miktarı ile farklı ölçeklerde toplanan spektral verileri ilişkilendirmişler ve bunun için 144 farklı vejetasyon indeksi kullanmışlardır. Sonuçlar kırmızı ile kırmızı kenar bölgesi arasındaki dalga boylarından üretilen indekslerin daha başarılı sonuçlar ortaya koyduğunu göstermektedir. Buna karşın 705 ile $750 \mathrm{~nm}$ arasındaki dalga boylarında yapılan basit oranlama ve bu dalga boyları kullanılarak üretilen vejetasyon indekslerinin klorofil içeriğini tahmin etmede yüksek düzeyde başarılı sonuçlar ürettiği yönünde bulgular da mevcuttur (Chen vd., 2007; Sims ve Gamon, 2002; Wu vd., 2008). Bütün bu sonuçlara rağmen literatürde hangi hiperspektral indeksin klorofil içeriğini belirlemede en başarılı sonucu ürettiği konusunda bir uzlaşma yoktur.

$\mathrm{Bu}$ araştırmanın ilgili literatüre katkı sunmak için koyduğu hedef; Akdeniz makro ekosistemi içerisinde yer alan ve farklı yükselti basamaklarındaki otlaklarda klorofil düzeyinin belirlenmesi için uygulanabilecek en güçlü band kombinasyonlarını ortaya koymaktır.

\section{AMAÇ VE YÖNTEM}

\subsection{Amaç}

$\mathrm{Bu}$ çalışmanın temel amacı, hiperspektral uzaktan algılama tekniklerinin otlaklardaki temel biyokimyasal parametrelerden biri olan klorofil içeriğinin tahminindeki potansiyelinin ortaya konulmasıdır. Araştırmanın ölçeği kanopi düzeyi ile sınırlandırılmıştır. Temel araştırma sorusu ise; "Otlak sahalarda yayılmış olan ot vejetasyonunun klorofil içeriğinde (bundan sonra Kİ olarak anılacaktır) meydana gelen varyasyonları en güçlü biçimde açıklayan indeks-model kombinasyonu hangisidir?" şeklinde belirlenmiştir. 
2.2. Çalışma Alanı, Örneklem Sahaları ve Örnekleme Zamanlaması

Çalışma, Kahramanmaraş il sınırları içerisinde gerçekleştirilmiştir (Şekil 1). Çalışma sahaları genel itibariyle Akdeniz ve İran-Turan flora bölgelerinin geçiş kuşağında yer alan bir vejetasyon karakterine sahiptir. Farklı yükselti basamaklarında farklı ekolojik koşulların ortaya çıkıyor olması, otlaklardaki vejetasyonun biyofiziksel ve biyokimyasal yapıları üzerinde etkili olduğundan örneklem sahalarının belirlenmesinde yükselti faktörü esas alınmış ve üç farklı yükselti basamağından örneklem sahası belirlenmiştir. Bu sahalar; yaklaşık $500 \mathrm{~m}$ yükseltiye sahip Kahramanmaraş Sütçü İmam Üniversitesi Avşar Kampüsünün güneyinde bulunan kampüs mevkii (Saha 1), yaklaşık 1200 m yükseltiye sahip, Başkonuş dağının kuzey yamacında bulunan Yaylaüstü köyü mevkii (Saha 2), ve yaklaşık 1400 m yükseltiye sahip, Başkonuş dağının batı yamacında bulunan Sersem yaylası mevkiidir (Saha 3). Bu sahaların seçiminde; ölçümler için ulaşılabilir, yükselti sınıflaması için genellenebilir ve vejetasyon paterni açısından belirgin farklılıklar içeriyor olmaları temel kriterler olarak sıralanabilir.

Farklı ekolojik koşulların hüküm sürmesi çalışma sahalarındaki vejetasyon kompozisyonu üzerinde de etkili olmuştur. Varol (2003) tarafından yapılan "Flora of Başkonuş Mountain (Kahramanmaraş)" başlıklı çalışma esas alınarak yapılan tanımlamalara göre Saha 1'deki dominant türler; Hordeum bulbosum L., ve Agropyron sp., Convolvulus cantabrica L., Adonis microcarpa DC., Lactuca sp., ve Fibigia eriocarpa (DC.) Boiss., Saha 2'de Trifolium sp., Bromus arvensis L., Secale sp., Bellis perennis L., ve Taraxacum crepidiforme DC. subsp., Saha 3 'te Hordeum bulbosum L., Secale sp., Aegilops speltoides Tausch var. speltoides, ve Trifolium sp. olarak belirlenmiştir. Ayrıca bu sahada Agropyron sp., Cynosurus echinatus L., ve Poa pratensis L. karışık halde bulunmaktadır.

Veriler, her bir çalışma sahasının ekolojik karakteri dikkate alınarak 2016 ve 2017 yıllarında, vejetasyon aktivitesinin pik yaptığı dönemlerde toplanmıştır. Bu dönemlerle ilgili (hem Türkiye ölçeğinde hem de bölgesel ölçekte) detaylı bilgiye Göksu vd. (2015) ile Karabulut (2006)'dan ulaşılabilir. Buradan hareketle verilerin toplanmasında; Saha 1 ( 500 m) için Nisan, Saha $2(\sim 1200 \mathrm{~m})$ için Mayıs ve Saha $3(\sim 1400 \mathrm{~m})$ için Haziran ayları tercih edilmiştir.

\section{3. Örnekleme Metodu ve Örnekleme Sayısı}

Örneklemlerin toplanmasında amaçlı (kasti) örneklem metodu ve çizgi transekt metodu olmak üzere iki farklı metot kullanılmıştır. Veri toplama sürecinin ilk yılında (2016) her üç çalışma sahasında da verilerin tamamı amaçlı örnekleme yöntemiyle toplanmıştır. Bu çalışma döneminde her bir sahadan 21 olmak üzere toplamda 63 örneklem elde edilmiştir (Tablo 1). İkinci y1lında ise (2017) Saha 1'den 50 örneklem daha toplanmış ve yine amaçlı örnekleme yöntemi tercih edilmiştir. Aynı teknikte 1srar edilmesinin nedeni sahadaki vejetasyon dağılışının oldukça heterojen bir örüntüye sahip olması ve bu örüntüde, herhangi bir istikamette kesintisiz ilerlemenin (çizgi

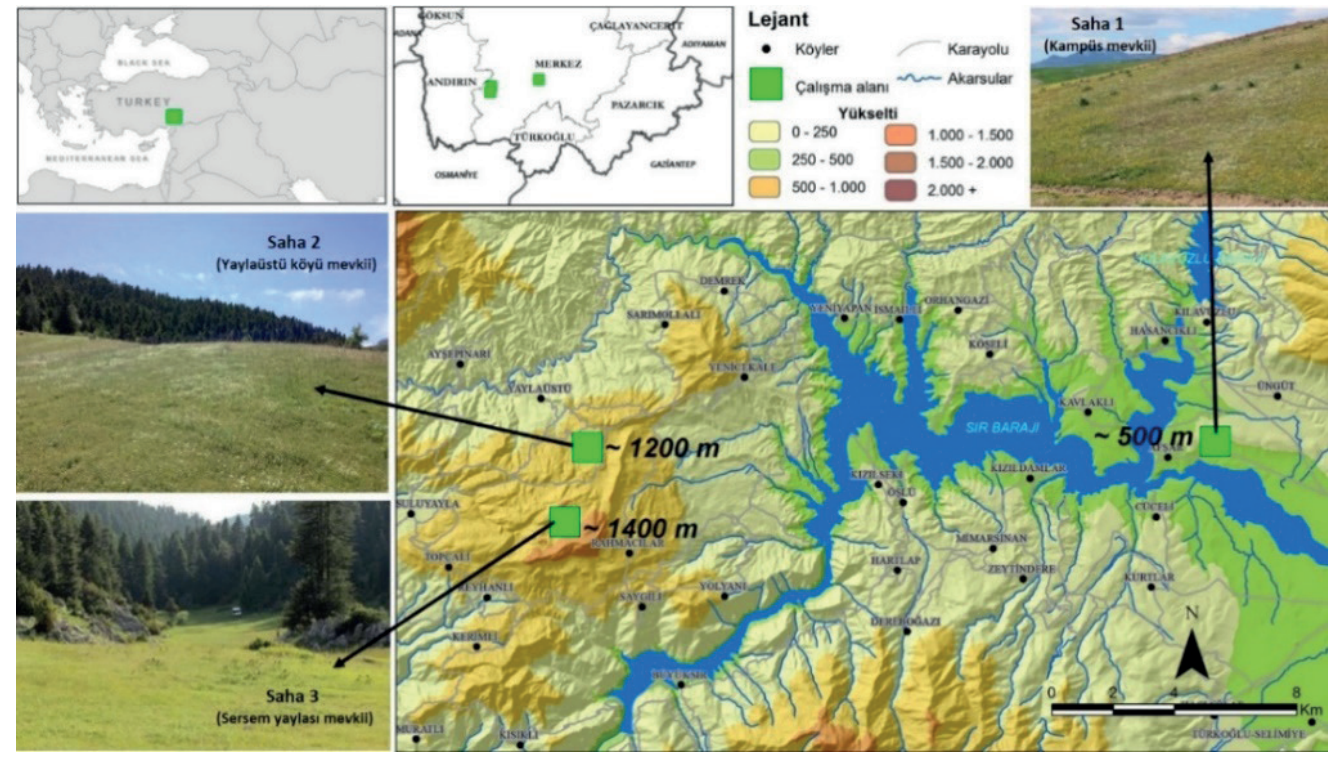

Şekil 1: Çalışma alanı ve örneklem sahalarının lokasyon haritası (Karakoç, 2019).

Figure 1: Location map of study area and of sampling sites. 
Tablo 1: Örneklem yöntemleri ve yıllara göre dağılımı.

Table 1: Sampling methods and distribution by years.

\begin{tabular}{lccccc}
\hline Kategoriler & \multicolumn{2}{c}{2016} & \multicolumn{2}{c}{2017} & TÜM \\
\hline Çalışma Sahası & Amaçlı & Transekt & Amaçlı & Transekt & Toplam \\
\hline Saha 1 $(\sim 500 \mathrm{~m})$ & 21 & - & 50 & - & 71 \\
Saha 2 $(\sim 1200 \mathrm{~m})$ & 21 & - & - & 50 & 71 \\
Saha 3 $(\sim 1400 \mathrm{~m})$ & 21 & - & - & 50 & 71 \\
TOPLAM & $\mathbf{6 3}$ & - & $\mathbf{5 0}$ & $\mathbf{1 0 0}$ & $\mathbf{2 1 3}$ \\
\hline
\end{tabular}

transekt), veri setinde sahayı temsil etmeyen örneklemlerin fazlaca yer bulması riskini doğurmasıdır. Sonuçta Saha 1 için toplamda 71 örnekleme ulaşılmıştır. Saha 2 ve Saha 3'te ise ikinci çalışma döneminde çizgi transekt yöntemi tercih edilmiştir. $\mathrm{Bu}$ yöntemle her iki çalışma sahasından da 125 m'den oluşan iki transekt (toplamda 250'şer m) belirlenmiş ve veriler her $5 \mathrm{~m}$ 'de bir yerleştirilen $50 X 50 \mathrm{~cm}$ 'lik kuadratlar içerisinden toplanmıştır. Böylece her 125m'lik transekt güzergâhından 25 'er, toplamda da 50 'şer örneklem daha toplanarak Saha 2 ve Saha 3 için de toplamda 71'er örnekleme ulaşılmıştır. Tüm veri toplama sürecinin sonunda ise her bir çalışma sahasından 71 olmak üzere toplamda 213 noktadan örneklem toplanmıştır (Tablo 1).

\subsection{Spektral İmzaların Toplanması ve Klorofil İçeriği Ölçümleri}

Veri toplama sürecinin ilk aşaması belirlenen test alanlarından spektral imzaların toplanmasıdır. Bu amaçla ASD FieldSpec ${ }^{\circledR}$ marka el tipi (HandHeld) spektroradyometre (Analytical Spectral Devices, Inc., Boulder, CO, USA) kullanılmıştır. Cihazın spektral ranjı 325-1075 nm arasındadır ve $1 \mathrm{~nm}$ aralıklarla ölçüm yapma kapasitesine sahiptir. Böylece her ölçümde 751 bantta veri toplanmıştır. Cihaz üzerinde $25^{\circ}$ lik optik bulunmaktadır. Bu nedenle ölçümler kanopinin yaklaşı olarak $75 \mathrm{~cm}$ üzerinden yapılmıştır (He, 2008: 64; Karabulut, 2018: 197). Spektroradyometre ölçümleri için hava koşullarının durumu ve ışığın geliş açısı oldukça önemlidir. Bu nedenle ölçümler rüzgârsız ve bulutluluğun az olduğu günlerde, güneş açısının en az değişim gösterdiği saat 10:00-14:00 arasında yapılmıştır. Ayrıca 1şık koşullarındaki değişime bağlı olarak ortaya çıkabilecek hataları engellemek için yaklaşı 1015 ölçümde bir, beyaz kalibrasyon paneli (spektralon) kullanılarak kalibrasyon işlemi gerçekleştirilmiş̧ir. Her bir kuadrat içerisinden art arda olacak şekilde 9 kez ölçüm yapılmış, veri analizi aşamasında ise bu 9 ölçümün ortalaması alınarak ölçülen sahanın spektral verisi olarak kaydedilmiştir. Böylece objedeki hareket veya cihazdaki titreme gibi olumsuzluklar en aza indirilmeye çalışılmıştır.
Klorofil ölçümleri için kanopi düzeyinde göreceli klorofil ölçümleri yapan Fieldscout CM 1000 (Spectrum Technologies, Inc., Plainfield, USA) marka lazerli klorofilmetre kullanılmıştır (Chang-Hua vd., 2010: 636). Cihaz kanopi düzeyindeki klorofili 0 999 değerleri arasında ölçeklendirilmiş (göreceli) klorofil indeksi(CM1000 indeksi) şeklindeölçmektedir. Buölçeklendirilmiş veri laboratuvar koşllarında $\mu \mathrm{g}$ cinsinden elde edilen klorofil verisi ile \%87 ila \%95 arasında bir korelasyona sahiptir (Chen vd., 2007: 74). Ölçümler, klorofilmetrenin kanopi üzerinden yaklaşık olarak $1.2 \mathrm{~m}$ yükseklikten hedefe odaklanmasıyla gerçekleştirilmiştir. Her kuadrat içerisinde 4 kez üst üste ölçümler yapılmış ve daha sonra bu ölçümlerin ortalaması alınarak klorofil içeriği (CM 1000) olarak kaydedilmiştir. Ölçümler, havanın açık ve rüzgârsız olduğu günlerde, Güneş'in yeryüzüne geliş açısının en az değiştiği saat 10.00 ile 14.00 arasinda ve benzer parlaklık indeksi (brightness index/BRT) koşullarında yapılmıştır.

\subsection{Veri Analizi}

\subsubsection{Veri Kategorizasyonu ve Sinıflandırması}

Analizler, Kategori I ve Kategori II olmak üzere iki temel kategori üzerinden kurgulanmıştır. Bu iki kategori de kendi içinde iki/üç sınıf oluşturmuş ve değerlendirmeler toplamda $5 / 6$ sınıf üzerinden yapılmıştır (Tablo 2).

Tablo 2. Veri analizinde uygulanan kategorizasyon ve sınıflandırmalar. Table 2. Categorization and classifications used in data analysis.

\begin{tabular}{cc}
\hline $\begin{array}{c}\text { Kategori I } \\
\text { (saha- temelli) }\end{array}$ & $\begin{array}{c}\text { Kategori II } \\
\text { (miktar-temelli) }\end{array}$ \\
\hline Saha 1 $(\sim 500 \mathrm{~m})$ & Düşük Ki (0-300 CM1000) \\
Saha 2 $(1200 \mathrm{~m})$ & Yüksek Ki $(300+$ CM1000) \\
Saha 3 $(\sim 1400 \mathrm{~m})$ & \\
\hline
\end{tabular}

Birinci temel kategoride (Kategori I), çalışılan her bir saha kendine has (unique) dinamikleri bakımından bir bütün olarak ele alınmış ve böylece saha-temelli bir yaklaşıma göre oluşturulmuştur. $\mathrm{Bu}$ kategori de kendi içerisinde "Saha 1 ( $500 \mathrm{~m})$ ), "Saha 2 ( 1200m)" ve "Saha 3 ( 1400m)" olmak üzere üç sınıfta ele alınmıştır. Bu sınıflamadaki temel amaç, çalışma sahalarının farklı yükselti basamaklarında yer alması ve bu bağlamda sahalardaki vejetasyonun benzersiz ekolojik dinamiklerin etkisi altında gelişim göstererek kendine has bir karakter oluşturacağı varsayımıdır.

İkinci temel kategori ise (Kategori II), benzer biyofiziksel/ biyokimyasal niceliklere sahip vejetasyonun (örneğin klorofil içeriği) 1şık ile ilişkilerinin de benzer olacağ 1 varsayımı (miktartemelli yaklaşım) ile oluşturulmuştur. Bu yaklaşımla Kategori II 
'de kendi içerisinde iki sınıfa ayrılmıştır. Bunlar; "Düşük klorofil içeriği (Düşük KI)" ve "Yüksek klorofil içeriği (Yüksek KI)" sınıflarıdır. Bu sınıflamada, Kategori I'den farklı olarak, düşük ve yüksek klorofil içeriği sınırının nereden geçtiğini ön analizlerle ortaya koymak gerekir. Bunun için herhangi bir sınıflama olmaksızın tüm verilerin bir arada değerlendirildiği veri setinin tanımlayıcı istatistikleri incelenmiş (Tablo 4), aritmetik ortalama ve medyanın 290 CM1000 civarında olduğunu görülmüşs, standart sapma ve kartillerin dağılışının da hesaba katılmasıyla 300 CM1000 değerinin düşük-yüksek Kİ sınırının ayrımı için uygun olduğu kanaatine varışmıştır. Öte yandan oran-temelli indekslerin saturasyon etkisine hassas oldukları bilindiğinden (Jiang vd., 2006:2512) bu kategorizasyon ve sinıflamanın bir diğer hedefi de saturasyon etkisinin ortaya çıkış eşiğininin gözlemlenmesidir.

\subsubsection{Spektral Eğrilerin Üretilmesi ve Vejetasyon İndekslerinin Oluşturulması}

Spektral eğriler, vejetasyonun fotosentez aktivitesi hakkında görsel yorumlama yapmak için oldukça kullanışlı bir gösterim biçimidir (Karabulut vd., 2014:147). Bu nedenle kuadratlar içinde yapılan spektral ölçümler bitki yansıma grafiklerine dönüştürülmüş ve görsel yorumlama için kullanılmıştır. Bu işlemin ilk adımı olarak spektroradyometre ile toplanan radyans verileri reflektans değerlerine dönüştürülmüştür. $\mathrm{Bu}$ dönüşüm için formül (1) kullanılmıştır (Peddle et al., 2001:208).

$$
R_{(\lambda)}=\frac{L_{(\lambda)}}{S_{(\lambda)}} \times \operatorname{Cal}_{(\lambda)} \times 100
$$

Burada $L(\lambda)$; hedefin radyant dalga boyunu (bitkiden ölçülen radyans değerini), $S(\lambda)$; kalibrasyon panelinden elde edilen radyans değerini, $\mathrm{Cal}(\lambda)$; kalibrasyon faktör değerini göstermektedir. Sonucun 100 ile çarpılmasılyla da reflektans değerleri yüzde cinsine dönüştürülmektedir.

\subsubsection{Vejetasyon İndekslerinin Oluşturulması}

Toplanan Kİ verileri ile spektral veriler arasındaki ilişkilerden kantitatif sonuçlar elde edebilmek için oran-temelli vejetasyon indekslerinden (ratio-based vegetation indices) yararlanılmıştır. Dalga boyu spektralarından indeks değerlerinin elde edilme işlemi, seçili dalga boylarının (bandların) birbirine oranlanması ile elde edilir. Oranlama öncesinde bandlar arasında aritmetik işlemler de uygulanabilir. Bu çalışmada kullanılan hiperspektral vejetasyon indeksleri daha önce Karakoç (2019) tarafindan sınanmış olan vejetasyon indeksi veri tabanı içinden seçilmiş, KI'deki varyasyonları en yüksek açıklama gücüne sahip 6 indeks üzerine odaklanmıştır (Tablo 3).
Tablo 3. Çalışmada kullanılan vejetasyon indeksleri'. Table 3. Vegetation Indices Calculated from Spectra.

\begin{tabular}{|c|c|c|}
\hline $\begin{array}{l}\text { Indeks adı Kullanılan } \\
\text { dalga boyları (nm) }\end{array}$ & Formül & Kaynak \\
\hline $\begin{array}{l}\text { Simple Ratio } \\
\text { SR }(550,800)\end{array}$ & $\frac{R_{800}}{R_{550}}$ & $\begin{array}{l}\text { Buschman ve } \\
\text { Nagel (1993) }\end{array}$ \\
\hline $\begin{array}{l}\text { Simple Ratio } \\
\text { SR }(560,810)\end{array}$ & $\frac{R_{810}}{R_{560}}$ & Xue vd., (2004) \\
\hline $\begin{array}{l}\text { Simple Ratio } \\
\text { SR }(710,750)\end{array}$ & $\frac{R_{750}}{R_{710}}$ & $\begin{array}{c}\text { Zarco-Tejada } \\
\text { vd., (2001) }\end{array}$ \\
\hline $\begin{array}{l}\text { Normalized Difference } \\
\text { Vegetation Index } 2 \\
\text { NDVI2 }(600,800)\end{array}$ & $\frac{R_{800-}-R_{600}}{R_{800+} R_{600}}$ & Ma vd., (1996) \\
\hline $\begin{array}{l}\text { Normalized Difference } \\
\text { Vegetation Index } \\
\operatorname{NDVI}(680,710,750)\end{array}$ & $\frac{R_{750-} R_{710}}{R_{710}-R_{680}}$ & $\begin{array}{l}\text { Dash ve Curran } \\
\qquad(2004)\end{array}$ \\
\hline $\begin{array}{l}\text { Normalized Difference Index } 2 \\
\text { NDI2 }(680,710,850)\end{array}$ & $\frac{R_{850-R_{710}}}{R_{850-} R_{680}}$ & Datt (1999) \\
\hline
\end{tabular}

Tablo 4. Tüm kategorilerdeki tüm veriler için tanımlayıcı istatistikler ve normallik testleri.

Table 4. Descriptive statistics and normality tests for all data in all categories.

\section{TÜM KATEGORILERDEKI TÜM VERILER}

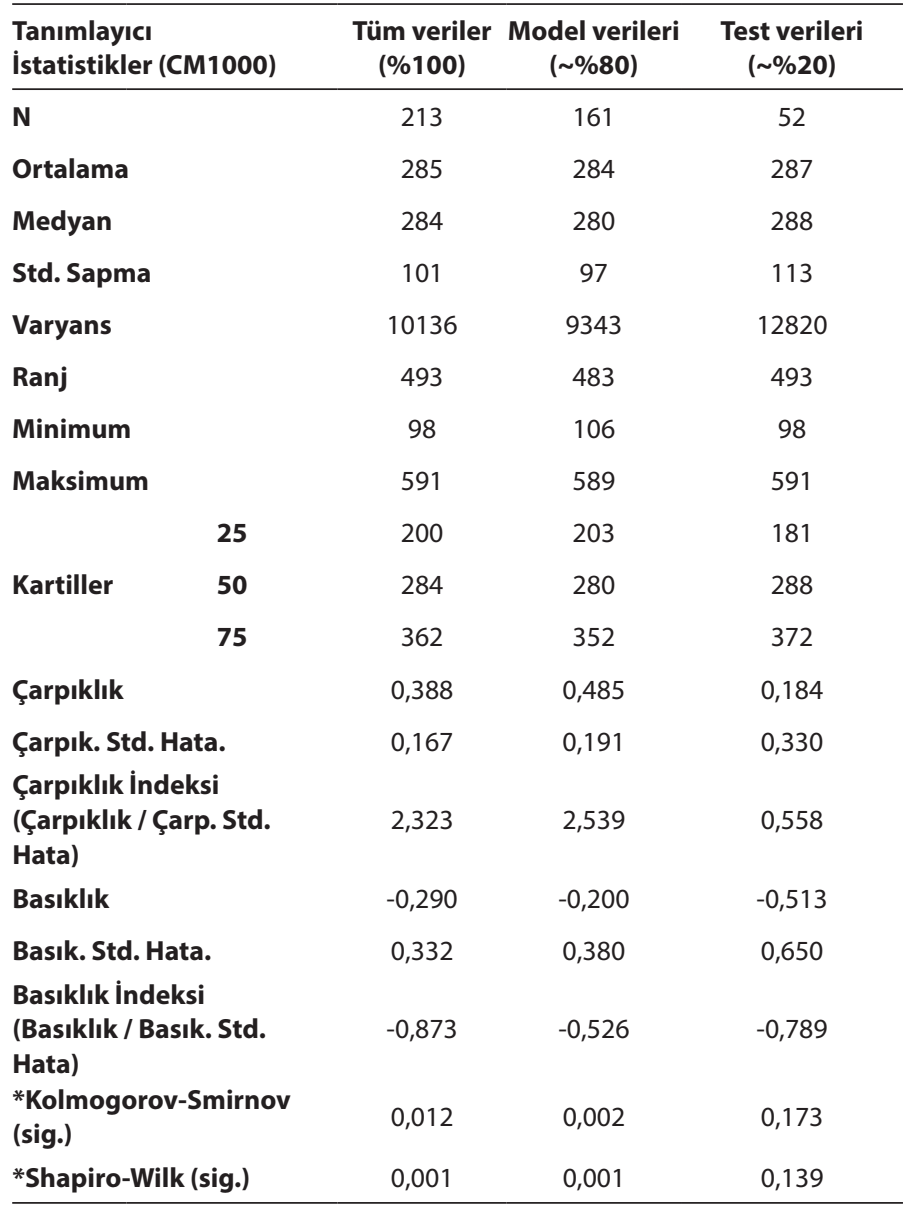

* Not: sig. < 0.05: \%95 güven aralığında anlamli; sig. < 0.01: \%99 güven aralığında anlamlı. 


\subsection{4. İstatistiksel Analizler}

Çalışmada model fonksiyonları kullanılacağı için veri seti ilk aşamada iki temel gruba ayrılmıştır. Bunlardan birincisi; modelin inşa edileceği ve verilerin yaklaşı olarak \%80'ini kapsayan "Model" veri seti grubu, ikincisi ise; verilerin yaklaşık olarak \%20'sini kapsayan ve oluşturulan model fonksiyonunun test edilmesini sağlayan "Test” veri seti grubudur.

Kİ verilerinden oluşan bu veri setlerinin ilk olarak tanımlayıcı istatistikleri ortaya konulmuştur. Ortalama, mod ve medyan gibi frekans dağılımının tipik göstergeleri merkezi eğilim ölçülerini temsil ederken ranj, standart sapma, varyans ve kartiller gibi göstergeler de veri setindeki yayılım ölçülerini temsil eder (McGrew vd. 2014: 39). Bu ölçülerden aritmetik ortalama, mod ve medyanın eşit ya da yakın olması dağılımımın normalliği üzerine kabulleri destekler (Demir vd., 2016:133). Daha sonra normallik testleri uygulanmıştır. Bunun için tüm verilerin bir arada değerlendirildiği veri setinde ilk aşamada frekans dağılımları (histogramlar) oluşturulmuş ve veri setindeki gözlemlerin eğilimleri ortaya konulmuştrr. Daha sonra da Q-Q grafikleri oluşturularak veri setindeki bireysel eğilimlerin normallik sınırlarını ne kadar zorladığı üzerine çıkarımlar yapılmıştır. Bu yöntemde gözlem değerleri (x ekseninde yer alır) büyüklüklerine göre sıralanır ve beklenen normal dağılım değerlerine (y ekseninde yer alır) karşlık gelecek şekilde grafik oluşturulur (Çokluk vd., 2012: 15).

Grafiksel gösterimler "normale yakın/normalden uzak" gibi betimleyici ve göreceli çıarımlar yapmak için kullanışlı sonuçlar üretebilir. Buna karşın istatistiksel seçenekler, dağılımın önceden belirlenen eşiklere ne kadar yakın veya uzak olduğunu kesin ve objektif olarak tespit eder. Bunlardan en sık kullanılanları çarpıklık ve basıklık ile Kolmogorov-Smirnov ve Shaphiro-Wilk testleridir (Genceli, 2007: 307). Literatürde çarpıklık ve basıklık katsayılarının +1 ile -1 , çarpıklık ve basıklık indekslerinin de +2 ile -2 arasında kaldığı sürece normal kabul edilebileceği şeklinde yaygın bir kabul de vardır (Demir vd., 2016: 133; Çokluk vd., 2012: 16; Hair vd., 2017: 83; Morgan vd., 2011: 51). Bu indeksler çarpıklık ve basıklık katsayılarının kendi standart hatalarına bölünmesi ile elde edilir. Kolmogorov-Smirnov ve Shaphiro-Wilk testlerin de gözlem sayısının 300'den az olduğu durumlarda daha başarılı sonuçlar ürettiği bilinmektedir (Kim, 2013: 52). Bu test sonuçlarının anlamlı çıkması dağılımın normal dağı̆lımdan anlamlı bir şekilde farklı olduğunu gösterir (Çokluk vd., 2012: 16).

Spektral veriler ise iki şekilde değerlendirilmiştir. Birincisi spektral yansıma eğrilerinin yorumlanması, ikincisi de vejetasyon indeksleri ile Kİ verilerinin modellenmesi şeklindedir.
Görsel yorumlamada farklı Kİ özelliklerine sahip örneklemlerin karşılaştırılmasında anahtar olarak kabul edilen spektral aralıklar kullanılmıştır. Örneğin, yüksek düzeyde klorofil içeren bir bitki, göreceli olarak daha düşük düzeyde klorofil içeren bir bitkiye göre kırmızı ışığı daha çok yutar. Böylece yansıma eğrisindeki kırmızı bölgeye odaklanarak hangi örneklemin göreceli olarak daha fazla klorofil içerdiği hakkında bilgi çıkarılabilir. Hangi dalga boyunun vejetasyonun hangi özelliği hakkında daha fazla bilgi barındırdığına dair detaylı bilgilere Lillesand vd., (2018) ve Karabulut (2019)'dan ulaşılabilir. Anahtar spektral aralıklar kullanılarak spektral eğrilerin yorumlanması her ne kadar vejetasyon hakkında genel bilgiler verip örneklemleri kıyaslama imkânı sunsa da bu yöntem ampirik çıkarımlar veya kantitatif analizler için yeterli değildir. Bu tür analizler için vejetasyon indekslerinin kullanılması ve istatistiksel ilişkiler kurulması gerekir. Vejetasyon indekslerinin KI'de meydana gelen varyasyonları tahmin etmedeki yeteneklerinin sınanması için regresyon analizleri tercih edilmiştir.

Regresyon analizleri, değişkenlerden birisi belirli bir birim farklılaştığı zaman, diğer değişkende nasıl bir tepkinin oluşabileceğini ortaya koyar. Başka bir anlatımla bağımsız bir değişkenin bilinen değerleri için bağımlı değişkenin alacağı değerleri tahmin etmede kullanılır (Büyüköztürk, 2004: 87). Bu araştırmada regresyon modelleri oluşturulurken "üstel" (exponential), "doğrusal" (linear), "logaritmik" (logarithmic) ve "üs" (power) fonksiyon modelleri sınanmış, en yüksek determinasyon katsayısına $\left(\mathrm{R}^{2}\right)$ sahip fonksiyon seçilerek açıklayıcı model olarak tercih edilmiştir. (He vd., 2009: 2515; Jin vd., 2014: 1501). Böylece bilinen indeks değerlerinden hareketle bilinmeyen Kİ parametresi için vejetasyon indekslerinin tahmin gücü modellenmiştir.

Model performansinın denetlenmesinde ise standart bir istatistiksel metrik olan Hata Kareleri Ortalamasının Karekökü (RMSE/root mean square error) kullanılmıştır (Chai ve Draxler, 2014). Burada;

$$
R M S E=\sqrt{\frac{\sum_{i}^{n}=1\left(Y_{i}-Y_{i}^{\prime}\right)^{2}}{N}}
$$

$Y_{\mathrm{i}}=$ ölçülen parametreyi,

$Y_{\mathrm{i}}^{\prime}=$ tahmin edilen parametreyi,

$N$; gözlem sayısını ifade etmektedir.

$\mathrm{Bu}$ parametre hesaplanırken ilk önce gözlenen değer ile tahmin edilen değer arasındaki hata (fark) hesaplanıp bu hatanın kareleri toplanır. Daha sonra bu hataların kareleri toplamı gözlem sayısına bölünerek elde edilen değerin karekökü alınır. 


\section{BULGULAR}

\subsection{Tanımlayıcı istatistikler ve Normallik Testleri}

Tanımlayıcı istatistikler, çalışma alanlarından elde edilen 213 örneklemin herhangi bir sinıflama ya da kategorizasyon yapılmaksızın, tüm verilerin değerlendirildiği veri seti (tüm kategorilerdeki tüm veriler) üzerinden hesaplanmıştır. Bu veri setinde "Tüm veriler", "Model verileri" ve "Test verileri" ayrı ayrı değerlendirilmiştir. Sınıflama ve kategorizasyon uygulanan veri setlerinden Kategori I (saha-temelli) ve Kategori II için ise yalnızca normallik testleri yapılmıştır.

Tüm verilerin bir arada değerlendirildiği veri setindeki tanımlayıcı istatistiklere bakıldığında $\mathrm{m}^{2}$ ye ortalama 290 CM1000 civarında Kİ düştüğü görülmektedir (Tablo 4). Standart sapmanın ortalamaya göre konumu, medyanın ortalamaya yakın oluşu ve kartillerin muntazam yayılışı gibi tanımlayıcı eğilimler ve yayılımlar homojen veya homojene yakın bir veri setinin varlığını işaret etmektedir. Çarpıklık ve basıklık değerlendirmesi yapıldığında, bu katsayıların her üç veri seti için de genel kabul olan +1 ve -1 aralığında olduğu görülür. Öte yandan çarpıklık indeksi parametresi eşik değer olan +2 ile -2 aralığının (test veri seti hariç) biraz dışında kalmışken, basıklık indeksi parametresi bu eşik değerlerin sınırları içersindedir. Bu değerlendirmeler ışığında tüm kategorilerin bir arada değerlendirildiği tüm verilerin çarpıklık bakımından normal dağılımın biraz dışında, basıklık bakımından ise homojen bir karakterde olduğu sonucuna varılabilir. Kolmogorov-Smirnov ve Shaphiro-Wilk testlerine göre ise tüm veriler ve model verilerinin normal dağılımın dışında, test veri setinin ise normal dağılıma sahip olduğu görülmektedir. Başka bir anlatımla tüm veriler ve model verileri anlamlı bir şekilde normalin dışında dağılmıştır (Tablo 4).

Frekans dağılımlarında normallik eğrisininin dengeli oluşu göze çarpmaktadır (Şekil 2). Başka bir anlatımla kuyruğun sağ veya sol tarafinda belirgin bir zorlama yoktur. Aynı durum her üç veri setinde de (tüm veriler, model verileri ve test veri setleri) benzer şekilde gözlenmektedir. Verilerin büyük bir kısmının 200-400 CM1000 aralığında toplsnmış olması ve basıklıkta leptokurtik bir eğilimin ortaya çıkmış olması dikkat çekicidir. Normal Q-Q dağılımlarına bakıldığında ise düşük ve yüksek değerlerin normal dağılımı zorladığı anlaşılır. Özellikle 250-400 CM1000 aralığındaki nicelik noktaları normallik çizgisine mükemmele yakın bir şekilde uyum sağlarken bu değerlerin altında veya üzerindeki değerler normalliğin dışında eğilimler göstermektedir (Şekil 2).
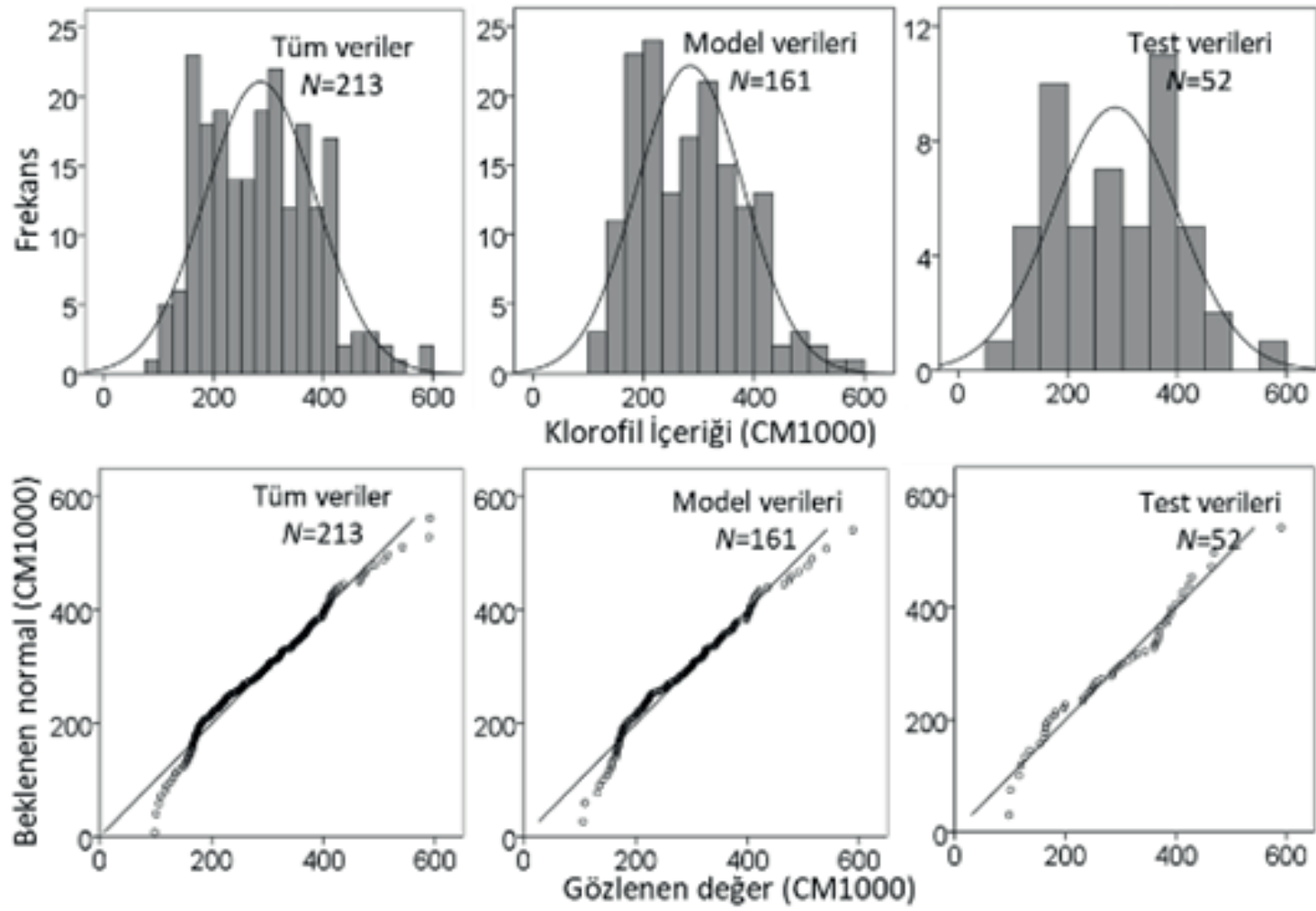

Şekil 2: Tüm kategorilerdeki tüm örneklemler için frekans ve Q-Q dağılımları.

Figure 2: Frequency and $Q-Q$ distributions for all samples in all categories. 
Verilerin iki temel kategoriye ayrılarak değerlendirildiği veri setlerine bakıldığında Kategori I'de yer alan sınıflardan Saha 1 verilerinin çarpıklık parametresi bakımından kritik değerlerin dışında olup homojen olmadığ 1 görülür. Aynı durum çarpıklık indeksi parametresi için de geçerlidir. Bu göstergeler bakımından Saha 1'in oldukça heterojen bir karakterde olduğu söylenebilir. Saha 2 ve Saha 3 ise her iki parametre bakımından da homojenlik sınırları içerisinde yer almaktadır. Kolmogorov-Smirnov ve Shaphiro-Wilk testlerinden elde edilen sonuçlarda ise Saha 1'in her iki testte de normalin dışında, Saha 2 ve Saha 3'ün normallik sınırları içinde bir dağılıma sahip olduğu görülmektedir.

Kategori II'de, Yüksek Kİ sınıfi hem çarpıklık hem de çarpıklık indeksi parametreleri bakımından normalin dışındadır. Düşük Kİ sınıfı ise her iki parametre bakımından da homojen kabul edilebilir. Buna göre Düşük Kİ sınıfı her parametrede de homojenlik koşullarını sağlarken Yüksek Kİ sınıfı hiçbir parametrede bu koşulları sağlayamaz. Kolmogorov-Smirnov ve Shaphiro-Wilk testlerinden elde edilen sonuçlarda ise Düşük Kİ kategorisinin Kolmogorov-Smirnov testinde \%95 güven aralığında homojenlik koşulunu sağladığı fakat diğer durumlarda $\% 95$ ve $\% 99$ güven aralıklarında bu koşulu sağlayamadığ söyleneblir (Tablo 5).

\subsubsection{Spektral Eğriler}

Hem Kategori I hem de Kategori II'de yer alan sinıfların spektral grafikleri incelendiğinde, eğrilerin yeşil vejetasyonun tipik yansıma davranışıyla tam bir uyum içinde olduğu açıkça görülür (Şekil 3). Buna karşın her kategori ve bu kategoriler içindeki sınıflar arasında kayda değer farklılıkları bulunur. Örneğin Kategori I'de yer alan sınıfların ortalama eğrilerini gösteren grafik incelendiğinde, Saha 1'de, görünür bölgedeki en yüksek ortalama yansıma oranına yeşil bölgede ulaşıldığı $(\sim \% 15)$ fakat bunun mavi ve kırmızı bölge arasında belirgin bir tepe oluşturacak şekilde (yeşil pik) kontrast yaratmadığı dikkati çekmektedir. Buna karşın Saha 2 ve Saha 3'teki ortalama yansıma eğiliminin Saha 1'e göre çok daha düşük olduğu ( $\% 10)$ anlaşılmaktadır. Başka bir anlatımla Saha 2 ve Saha 3 'te mavi ve kırmızı bölgedeki yutulma hissedilir bir biçimde arttığı için (düşük yansıma) yeşil bölge belirgin bir tepe haline gelebilmiştir. Öte yandan Saha 2 ve 3'te kırmızı yutulma bölgesinde, örneklemler arası fark Saha 1'e göre daha azdır. Saha 2 ve 3'ün Saha 1'e göre daha homojen yapida olmaları bu durumun temel sebebi olduğu söylenebilir. Eğrilerin görünür bölgede birbirine en fazla benzediği çalışma sahası ise belirgin bir biçimde Saha 3'tür. Bu sahada örneklemlerin görünür bölgedeki yansımaları arasındaki varyasyon diğer sahalara nazaran daha az farklılık gösterir. Kırmızı yutulma bölgesi ise her üç çalışma alanında fark edilir düzeydedir ancak çalışma sahasının yükseltisi arttıkça yutulmanın şiddeti de artmaktadır. Kırmızı bölgedeki yutulmadan doğrudan klorofil sorumlu olduğundan yükselti arttıkça klorofil içeren örneklemlerin de arttığı çıkarımı yapılabilir.

Kategori II'de yer alan sinifların spektral eğrileri incelendiğinde ise Yüksek Kİ bulunan örneklemlerinin görünür bölgede daha homojen bir yansıma karakteristiği sergilemesi en dikkat çekici özellik olarak karşımıza çıkar (Şekil 3). Düşük Kİ sınıfında yer alan örneklemlerin görünür bölgedeki yansımaları belirgin bir biçimde fazla olmakla birlikte kırmızı yutulma bölgesinde \%20'nin üzerine çıkmıştır. Kİ arttıkça kırmızı yutulma bölgesi daha da belirginleşmekte ve örneklemler arasındaki varyasyon azalmaktadır. Kategori II'de dikkati çeken bir başka özellik de NIR bölgedeki yansımalarda ortaya çıan

Tablo 5: Kategori I ve Kategori II için normallik testleri.

Table 5: Normality tests for Category I and Category II.

\begin{tabular}{|c|c|c|c|c|c|}
\hline \multirow[b]{2}{*}{ Tanımlayıcı istatistikler (CM1000) } & \multicolumn{3}{|c|}{$\begin{array}{c}\text { KATEGORI I } \\
\text { (SAHA-TEMELLi) }\end{array}$} & \multicolumn{2}{|c|}{$\begin{array}{c}\text { KATEGORi II } \\
\text { (MiKTAR-TEMELLi) }\end{array}$} \\
\hline & $\begin{array}{c}\text { Saha } 1 \\
(\sim 500 \mathrm{~m})\end{array}$ & $\begin{array}{c}\text { Saha } 2 \\
(\sim 1200 \mathrm{~m})\end{array}$ & $\begin{array}{l}\text { Saha } 3 \\
(\sim 1400 \mathrm{~m})\end{array}$ & $\begin{array}{c}\text { Düşük Ki } \\
\text { (0-300 CM1000) }\end{array}$ & $\begin{array}{c}\text { Yüksek Ki } \\
(300+\text { CM1000) }\end{array}$ \\
\hline $\bar{N}$ & 71 & 71 & 71 & 119 & 94 \\
\hline Çarpıklık & 2,071 & 0,555 & 0,374 & $-0,048$ & 1,286 \\
\hline Çarpık. Std. Hata. & 0,285 & 0,285 & 0,285 & 0,222 & 0,249 \\
\hline $\begin{array}{l}\text { Çarpıklık İndeksi } \\
\text { (Çarpıklık / Çarp. Std. Hata) }\end{array}$ & 7,267 & 1,947 & 1,312 & $-0,216$ & 5,165 \\
\hline Basıklık & 5,666 & 0,192 & 0,855 & $-0,865$ & 2,069 \\
\hline Basık. Std. Hata. & 0,563 & 0,563 & 0,563 & 0,440 & 0,493 \\
\hline $\begin{array}{l}\text { Basıklık İndeksi } \\
\text { (Basıklık / Basık. Std. Hata) }\end{array}$ & 10,064 & 0,341 & 1,519 & $-1,966$ & 4,197 \\
\hline *Kolmogorov-Smirnov (sig.) & 0,000 & 0,200 & 0,200 & 0,045 & 0,007 \\
\hline *Shapiro-Wilk (sig.) & 0,000 & 0,065 & 0,594 & 0,006 & 0,000 \\
\hline
\end{tabular}

* Not: sig. < 0.05: \%95 güven aralığında anlamlı; sig. < 0.01: \%99 güven aralığında anlamlı. 


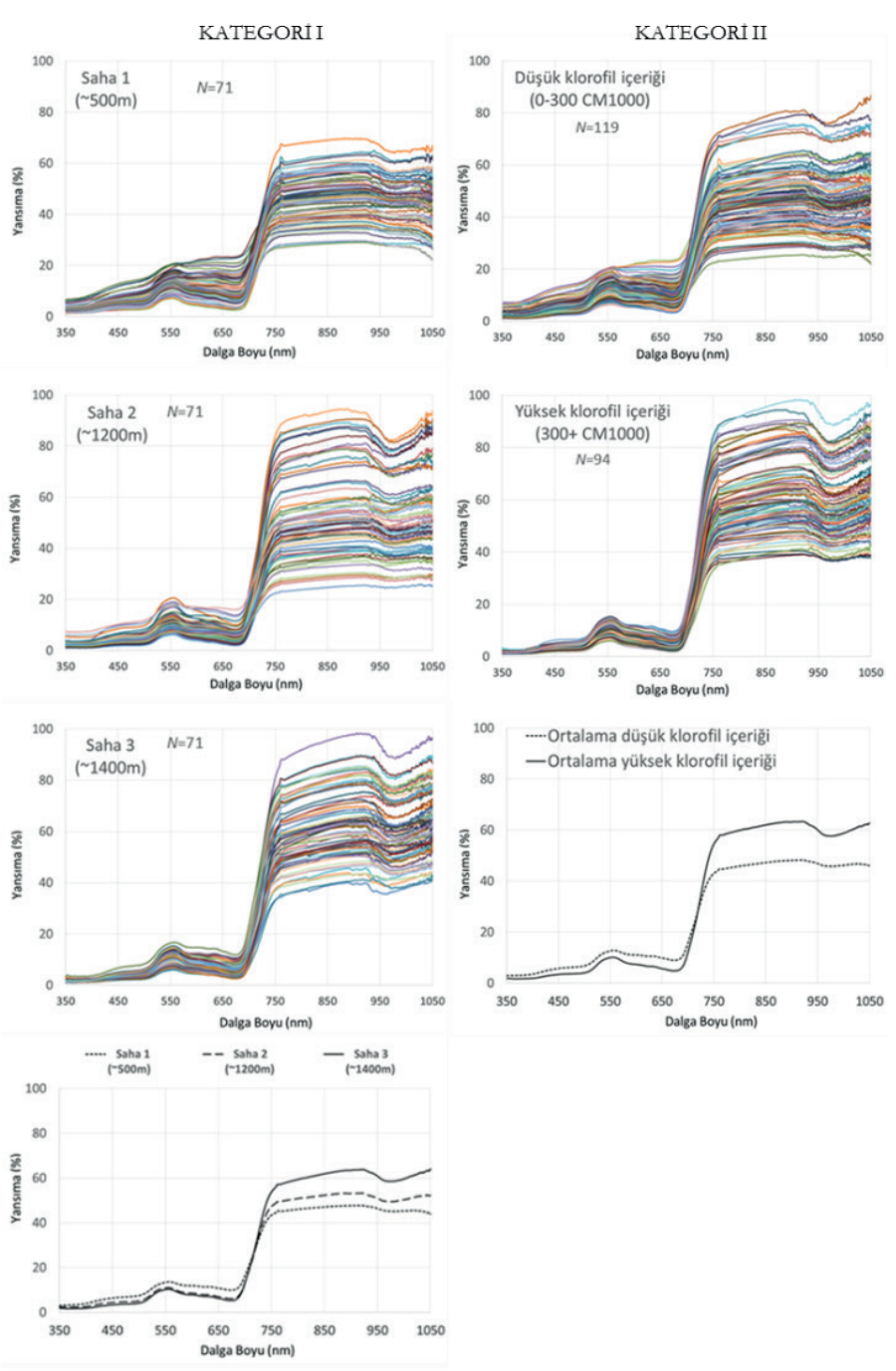

Şekil 3: Kategori I ve Kategori II'de yer alan sınıfların spektral grafikleri.

Figure 3: Spectral curves of classes in Category I and Category II.

değişkenliktir. Nitekim Düşük Kİ sınıfında en düşük NIR yansıması \%20'lerin biraz üzerinde iken Yüksek Kİ sınıfında bu oran \%40'lar civarındadır. Öte yandan Yüksek Kİ sınıfında maksimum NIR yansımaları mükemmele yakın bir düzeye ulaşıp \%100'e yaklaşmıştır. Düşük ve Yüksek Kİ sınıflarına dâhil olan tüm örneklemlerin ortalamalarına bakıldığında da aradaki fark belirgin bir şekilde ortaya çıkar. Düşük Kİ eğrisi kırmızı-kenar bölgesinin bir bölümü de dâhil olmak üzere görünür bölgenin tamamında daha yüksek yansıma karakteri göstermekte, yaklaşık 700 nm'lerden sonra durum tersine dönüp Yüksek Kİ sınıfı daha yüksek yansıma davranışı sergilemektedir.

\subsubsection{Vejetasyon İndeksleri}

Spektral eğrilerin betimsel yorumlaması, çalışma sahalarının genel yapısı ve örneklemlerin genel karakterleri hakkkında çıkarımlar yapmak için ideal bir analiz biçimidir ancak kantitatif çıktılar sunmaz. Bu nedenle Kİ ile spektral veriler arasındaki ilişkilerin analizi için oran-temelli vejetasyon indekslerinden (ratio-based vegetation indices) yararlanılmıştır. $\mathrm{Bu}$ indeksler kullanarak regresyon modelleri üretilmiş ve hangi indeksle oluşturulan hangi modelin, hangi kategorideki veri üzerinde daha açıklayıcı sonuçlar ürettiğine dair bulgular değerlendirilmiştir.

Buna göre; tüm verilerin bir arada değerlendirildiği veri setinde (tüm kategorilerdeki tüm örnekler) en güçlü model SR $(560,810)$ indeksi ile elde edilmiştir (Şekil 4). Bu indeks ile oluşturulan üs fonksiyon modeli, söz konusu veri seti için KI'de meydana gelen varyasyonları \%86'nın üzerinde bir açıklama gücüne sahiptir (Şekil 4(a)). Bununla birlikte Kİ miktarı arttıkça saçılma noktalarının regresyon eğrisinden belirgin bir biçimde uzaklaşmadığı dikkati çekmektedir (Şekil 4(c)). Bu da saturasyon etkisinin sözkonusu indeks-model kombinasyonunda kuvvetli bir etki yapmadığı şeklinde yorumlanabilir.

Kategori I'de yer alan sınıflar için yapılan analizlere göre Saha 1'de Kİ tahmini için en uygun vejetasyon indeksi SR $(550,800)$ olmuştur (Şekil 5(a)). Bu indeksle kurulan doğrusal (a)

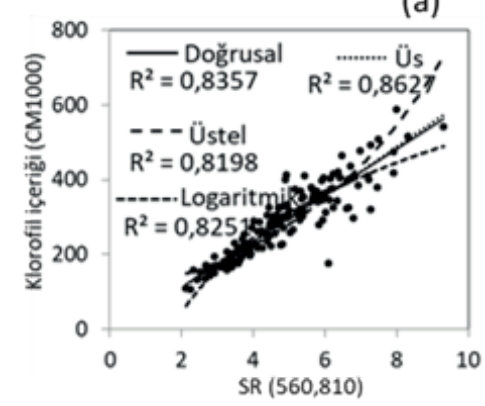

(b)

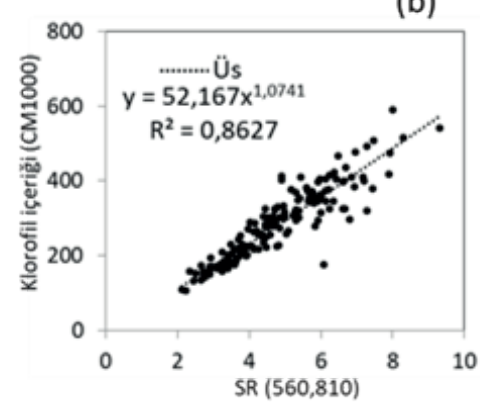

(c)

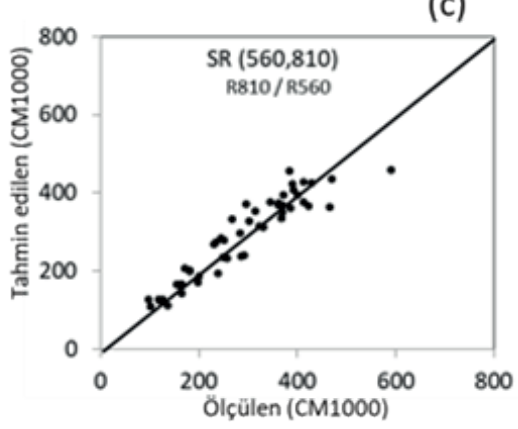

Şekil 4: Tüm kategorilerdeki tüm örneklemler için regresyon modelleri (a) tüm modeller, (b) en uygun model formülü, (c) modelin testi. Figure 4: Regression models for all samples in all categories (a) all models, (b) the fittest model formula, (c) test of the model. 
(a)

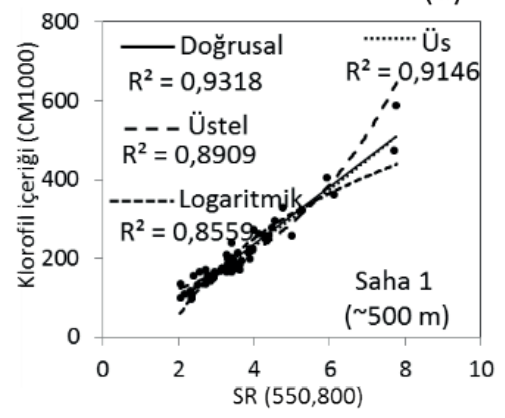

(d)

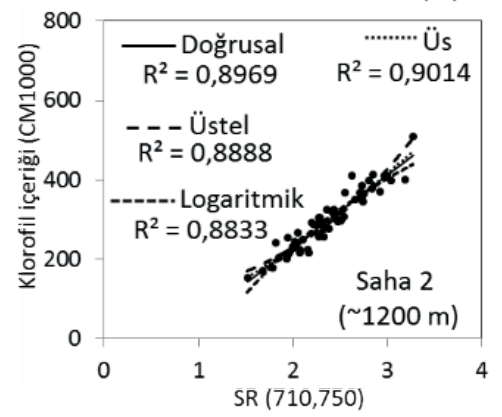

(g)

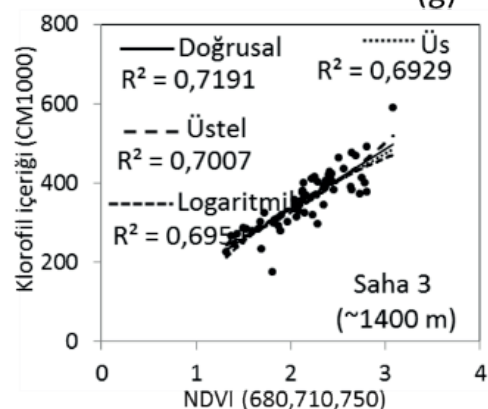

(b)

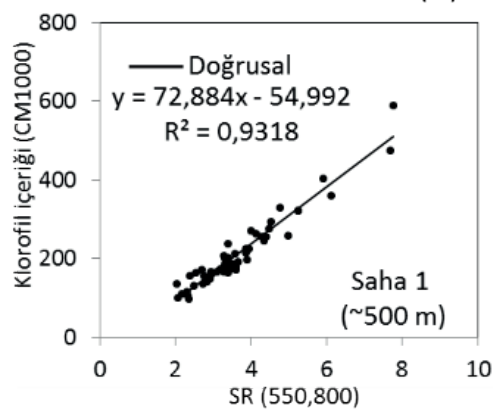

(e)

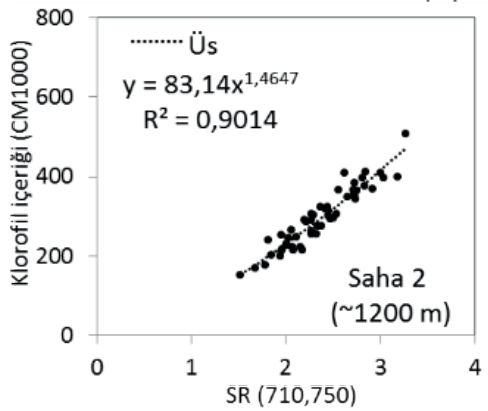

(h)

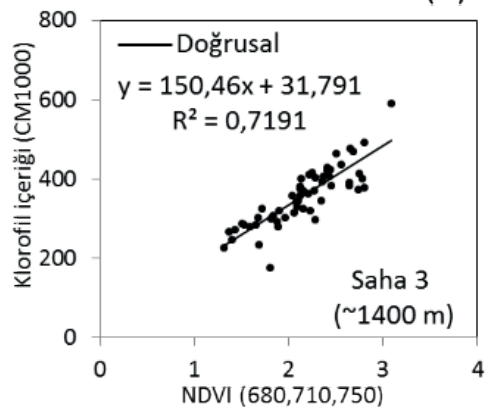

(c)

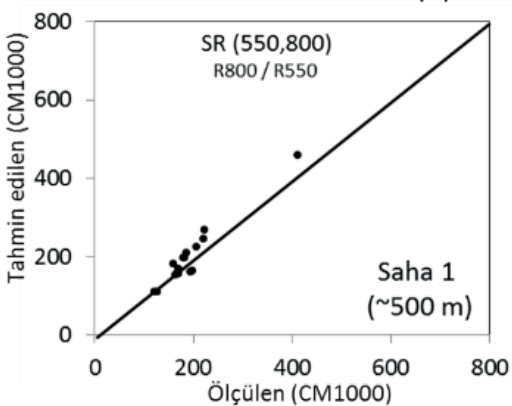

(f)

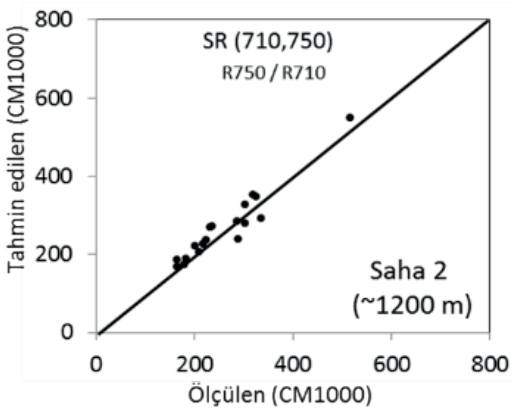

(i)

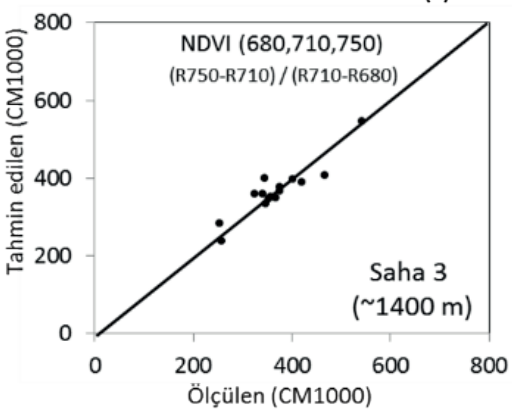

Şekil 5: Kategori I için oluşturulan regresyon modelleri (Tüm modeller; (a), (d) ve (g), en uygun model formülleri; (b), (e) ve (h) model testleri; (c), (f) ve (i)). Figure 5: Regression models for Category I (All models; (a), (d) and (g), the fittest model formulas; (b), (e) and ( $h$ ) model tests; (c), (f) and (i)).

modelin KI'de meydana gelen varyasyonları açıklama gücü \%93'ün üzerindedir (Şekil 5(b)). Buradaki en dikkat çekici durum kullanılan model fonksiyonları arasında en zayıfı olan logaritmik modelin dahi \%85'in üzerinde bir açılama gücüne ulaşmasıdır. Saha 2 için yapılan analizlerde ise bu sahadaki KI tahmininde SR $(710,750)$ indeksinin $\% 90$ civarında bir açılama gücüne sahip olduğu belirlenmiştir (Şekil 5(d)). Bu oran Saha 1'den farklı olarak üs model kullanılarak elde edilmiştir belirlenmiştir (Şekil 5(e)). Bu saha için aynı indeksle oluşturulan doğrusal modelin de $\% 89$ gibi yüksek bir açıklama gücüne sahip olmasının, sahadaki homojen yapı ile ilintiliği olduğu düşünülmektedir. Saha 3 için yapılan analizlerde ise en yüksek açıklama gücü NDVI $(680,710,750)$ indeksi ile elde edilmiştir (Şekil 5(g)). Burada da en yüksek açıklama gücüne doğrusal model ile ulaşılmıştır (Şekil 5(h)). Fakat diğer model sınıfları da \%71 açıklama gücüne sahip olan doğrusal model sınıfına çok yakın değerler üretmişlerdir. Esasen \%70'in üzerinde olan bu açıklama gücü literatürle kıyaslandığında azımsanmayacak bir değer olsa da Saha 1 ve Saha 2'ye göre düşük kalmaktadır.

Kategori II'de yer alan sınıflar için yapılan analizlede Düşük Kİ tahmininde en yüksek açıklama gücüne sahip vejetasyon indeksi NDVI2 $(680,800)$ olarak belirlenmiş̧ir (Şekil 6(a)). Bu indeks ile oluşturulan üstel modelin Düşük Kİ değerlerinde meydana gelen varyasyonları açıklama gücü \% $\% 7$ 'nin üzerindedir (Şekil 6(b)). Yüksek Kİ'de ise NDI2 $(680,710,850)$ indeksi en güçlü modeli üreten indeks olmuştur (Şekil 6(d)). Bu indeks ile kurulan üstel model ile \%63'ün üzerinde bir açıklama gücü elde edilmiştir (Şekil 6(e)). 
(a)

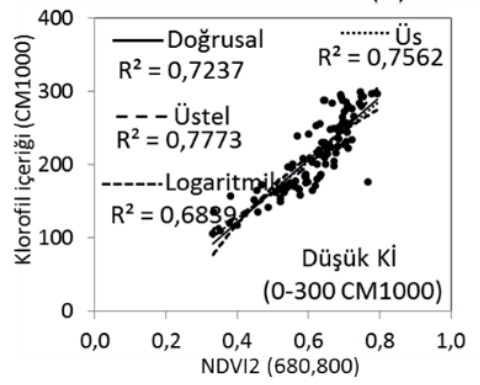

(d)

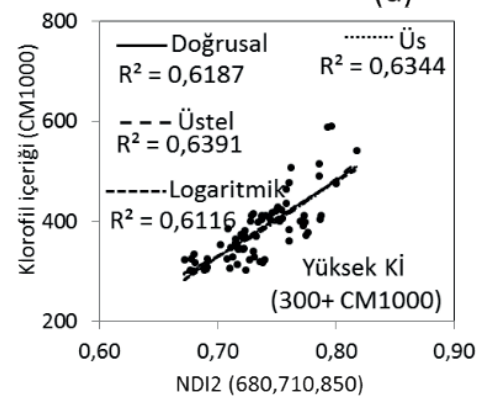

(b)

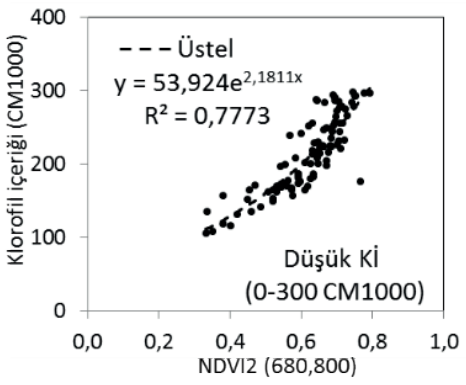

(e)

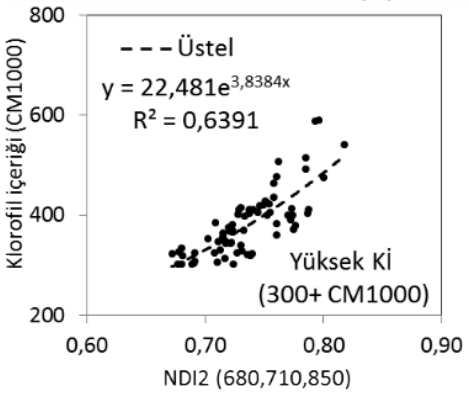

(c)

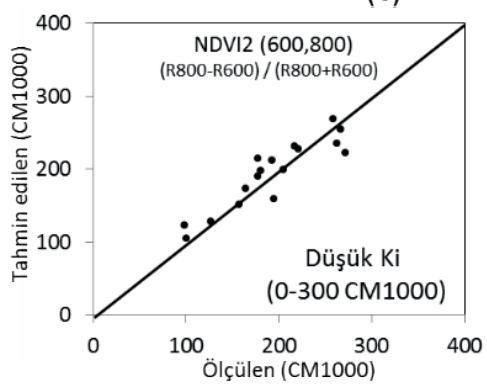

(f)

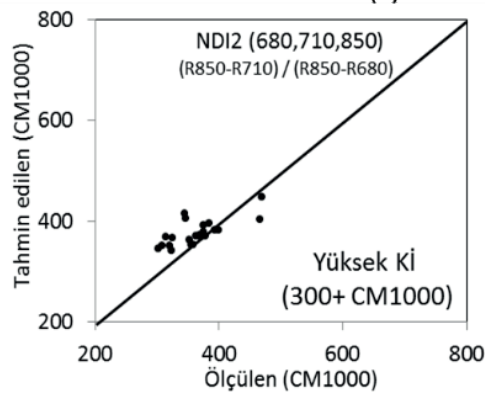

Şekil 6: Kategori II için oluşturulan regresyon modelleri (Tüm modeller; (a) ve (d), en uygun model formülleri; (b) ve (e), model testleri; (c) ve (f)). Figure 6: Regression models created for Category II (All models; (a) and (d), the fittest model formulas; (b) and (e), model tests; (c) and (f)).

Klorofil 450-650 nm'lerdeki dalga boylarını yutma, $550 \mathrm{~nm}$ civarındaki dalga boyunu ise yansıtma gibi temel bir karakeristiğe sahip olduğu için uzaktan algılama çalışmalarında önemli bir yere sahiptir. Öte yandan son yıllarda yapılan çalışmalarda kabaca 680-740 nm aralığında bulunan kırmızı kenar bölgesinin de klorofil için önemli bir gösterge olduğu yönünde bir ortak kanı vardır. Bu çalışmada kullanılan indeksler ve elde edilen açılama oranları 550-800 nm ve $680-850 \mathrm{~nm}$ aralığının KI'‘nin modellenmesinde \%90'ların üzerinde bir açıklama gücüne ulaşabildiğini göstermiştir. Bunun yanında Kİ ortalamalarının düşük ve heterojen veri setlerinde daha güçlü modellerin elde edilmiştir (Tablo 6).

\section{TARTIŞMA VE SONUÇ}

Literatürde de KI'de meydana gelen varyasyonları açıklama üzerine odaklanmış çok sayıda araştırma mevcuttur. Bu çalışmaların bir bölümü doğrudan (laboratuvar ortamında) alınan KI örnekleri üzerinden yürütülmüştür. Örneğin; Blackburn (1998), eğrelti otları üzerinde yaptığı araştırmada yaprak ve kanopi düzeyinde klorofil ve karotenoidi hiperspektral veriler ile ilişkilendirerek tahminler üretmeye çalışmıştır. PSSRa $\left(\mathrm{R}_{800} / \mathrm{R}_{680}\right)$ ve PSSRb $\left(\mathrm{R}_{800} / \mathrm{R}_{635}\right)$ indeksleri ile $\% 96$ 'lık bir açıklama gücüne ulaşmıştır. Carter ve Knapp (2001) 5 farklı bitki üzerinden yansıma, geçirgenlik ve emilimi

Tablo 6: Tüm kategorilerdeki tüm örneklemler için en yüksek açıklama gücü olan modeller ve hata hesaplamaları. Table 6: The fittest models and error calculations for all samples in all categories.

\begin{tabular}{|c|c|c|c|c|c|c|}
\hline \multicolumn{2}{|c|}{ Kategori/Sınıf } & İndeks & Model & $\mathbf{R}^{2}$ & Formül & RMSE (CM1000) \\
\hline \multicolumn{2}{|c|}{$\begin{array}{l}\text { Tüm Kategorilerdeki } \\
\text { Tüm Örneklemler }\end{array}$} & SR $(560,810)$ & Üs & 0,8627 & $y=52,167 x^{1,0741}$ & 38 \\
\hline \multirow{3}{*}{ 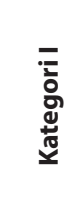 } & $\begin{array}{l}\text { Saha } 1 \\
(\sim 500 \mathrm{~m})\end{array}$ & SR $(550,800)$ & Doğrusal & 0,9318 & $y=72,884 x-54,992$ & 26 \\
\hline & $\begin{array}{l}\text { Saha } 2 \\
(\sim 1200 \mathrm{~m})\end{array}$ & SR $(710,750)$ & Üs & 0,9014 & $y=83,14 x^{1,4647}$ & 26 \\
\hline & $\begin{array}{l}\text { Saha } 3 \\
(\sim 1400 \mathrm{~m})\end{array}$ & NDVI $(680,710,750)$ & Doğrusal & 0,7191 & $y=150,46 x+31,791$ & 27 \\
\hline \multirow{2}{*}{ 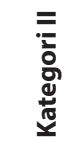 } & $\begin{array}{c}\text { Düşüuk Ki } \\
\text { (0-300 CM1000) }\end{array}$ & NDVI2 $(680,800)$ & Üstel & 0,7773 & $y=53,924 e^{2,1811 x}$ & 22 \\
\hline & $\begin{array}{c}\text { Yüksek Ki } \\
(300+\text { CM1000) }\end{array}$ & NDI2 $(680,710,850)$ & Üstel & 0,6391 & $y=22,481 e^{3,8384 x}$ & 33 \\
\hline
\end{tabular}


Kİ ile ilişkilendirdikleri çalışmalarında 567 ve 709 nm'lerde \%93 düzeyinde açıklama gücüne ulaşmışlardır. Darvishzadeh vd., (2008), Majella Ulusal Parkı, İtalya'da yaptıkları çalışmalarında 400-2400 nm arasında 584 band kullanarak vejetasyon indeksleri üretmişler ve bu indeksler ile Kİ arasında ilişkiler kurmuşlardır. Kİ tahminlerinde en güçlü dalga boylarını 747, 749, 1425, 1660, $2391 \mathrm{~nm}$ olarak tespit etmiş̧lerdir. Yin vd., (2016) ise Tibet platosu, Çin'de yaptıkları çalışmalarında Landsat-8 kullanarak $\mathrm{CI}_{\text {green }}$ ve $\mathrm{G}$ indeksleri kullanmışlar ve $\% 86$ düzeyinde bir açıklama gücüne ulaşmışlardır. Fakat bu yöntemler uzun ve pahalı analizler gerektiren laboratuvar çalışmalarını içerir.

Literatürde lazerli klorofilmetre uygulamalarının yaygın bir biçimde kullanılmasının en önemli sebebi hızlı ve ucuz olmasının yanında doğrudan elde edilen Kİ ile göreceli olarak ölçülen KI arasındaki güçlü ilişkilerin ortaya konulmuş olmasıdır (Chen vd., 2007). Bu ilişkiden hareketle göreceli klorofilmetre ölçümlerini mutlak klorofil miktarına dönüştürerek çalışmalarına dahil eden örnekler de mevcuttur (Yin vd., 2016:618). Darvishzadeh vd., (2008) yaprak alan indeksi (LAI) ile KI ölçümlerini ilişkilendirmişler ve $\% 50$ ile $\% 75$ arasında değişen açıklama gücüne ulaşmışlardır. Chang-Hua vd. (2010) ise kırmızı kenar bölgesi ile CM1000 ile toplanan Kİ verilerini ilişkilendirmişler ve \%70'in üzerinde bir açıklama gücü elde etmişlerdir.

\section{SON NOTLAR}

$\mathrm{Bu}$ çalışmanın bulguları tüm verilerin bir arada değerlendirildiği veritabanında $\% 85$ 'in üzerinde, saha-temelli oluşturulan kategorizasyonda Saha 3 dışında, \%90'ın üzerinde açıklama gücüne ulaşıldığını göstermektedir. Bu kapsamda ilgili literatürle kıyaslandığında başarılı olan indeks-model kombinasyonlarının geliştirildiği söylenebilir. Buna karşın miktar-temelli kategorizasyonda elde edilen açıklama gücü $\% 77$ ve $\% 64$ 'lerde kalmıştır. $\mathrm{Bu}$ durum yüksek klorofil içeriğinde saturasyon etkisinin belirgin hale geldiği şeklinde yorumlanabilir. Başka bir anlatımla vejetasyonun ışık ile olan ilişkisi klorofil miktarı belli bir eşiği aştıktan sonra karmaşıklaşmakta ve bu çalışmda kullanılan model fonksiyonları tarafından yeterince güçlü bir biçimde açıklanamamaktadır. Zira saturasyon problemi literatürün oldukça uzun süredir üzerinde durduğu temel sorunlardan biridir (Zhao vd., 2014:5370). Öte yandan farklı sahalardan toplanmalarına rağmen benzer Kİ niceliklerine sahip örneklemler bir araya getirilerek oluşturulan Kategori II'deki düşük açıklama düzeyleri çalışmada vurgulanması gereken sonuçlardan biri olarak karşımıza çıkmıştır. Her ne kadar benzer kimyasal niceliklere sahip olsalar da toplanan örneklemlerin, sahanın kendine has örüntüsü içerisinde ş̧ınım davranışının farklılaşabileceği ve kendi heterojen örüntüsü içerisinde daha anlamlı bilgiler ürettikleri de bu çalışmanın temel sonuçlarından biri olarak söylenebilir.

Teşekkür: Arazi çalışmalarındaki destekleri için Gökay GÖKSU, İlhami DOĞAN, Sercan BAHÇECİ ve Ahmet AVCU'ye teşekkürlerimizi sunarız.

Hakem Değerlendirmesi: Dış bağımsız.

Yazar Katkıları: Çalışma Konsepti/Tasarım- A.K., M.K.; Veri Toplama- A.K., M.K.; Veri Analizi/Yorumlama- A.K., M.K.; Yazı Taslağı- A.K., ; İçeriğin Eleştirel İncelemesi- M.K.; Son Onay ve Sorumluluk- A.K., M.K.

Çıkar Çatışması: Yazarlar çıkar çatışması bildirmemiştir.

Finansal Destek: Yazarlar bu çalışma için finansal destek almadığını beyan etmiştir.

Peer-review: Externally peer-reviewed.

Author Contributions: Conception/Design of Study- A.K., M.K.; Data Acquisition- A.K., M.K.; Data Analysis/Interpretation- A.K., M.K.; Drafting Manuscript- A.K. Critical Revision of Manuscript- M.K.; Final Approval and Accountability- A.K., M.K.

Conflict of Interest: The authors have no conflict of interest to declare.

Grant Support: The authors declared that this study has received no financial support.

\section{KAYNAKÇA/REFERENCES}

Blackburn, G. A. (1998). Quantifying chlorophylls and caroteniods at leaf and canopy scales: An evaluation of some hyperspectral approaches. Remote Sensing of Environment, 66(3), 273-285. https://doi.org/10.1016/S0034-4257(98)00059-5.

Buschman, C., \& Nagel, E. (1993). In vivo spectroscopy and internal optics of leaves as a basis for remote sensing of vegetation. International Journal of Remote Sensing, 14, 711-722. https://doi. org $/ 10.1080 / 01431169308904370$

Büyüköztürk, Ş. (2004). Sosyal bilimler için veri analizi el kitabı (4. bs). Ankara: PegemA Yayınları.

Carter, G. A., \& Knapp, A. K. (2001). Leaf optical properties in higher plants: Linking spectral characteristics to stress and chlorophyll concentration. American Journal of Botany, 88(4), 677-684. https:// doi.org/10.2307/2657068

Chai, T., \& Draxler, R. R. (2014). Root mean square error (RMSE) or mean absolute error (mae)? - Arguments against avoiding RMSE in the literature. Geoscientific Model Development, 7(3), 1247-1250. https://doi.org/10.5194/gmd-7-1247-2014

Chang-Hua, J. U., Tian, Y., Yao, X., Cao, W., Zhu, Y., \& Hannaway, D. (2010). Estimating leaf chlorophyll content using red edge parameters. Pedosphere, 20(5), 633-644. https://doi.org/10.1016/ S1002-0160(10)60053-7

Chen, J. C., Yang, M., \& Wu, S. T. (2007). Leaf chlorophyll content and surface spectral reflectance of tree species along a terrain gradient in Taiwan's Kenting National Park. Bot Stud, 48, 71-77. Erişim adresi: https://ejournal.sinica.edu.tw/ 
Curran, P. J., Dungan, J. L., \& Gholz, H. L. (1990). Exploring the relationship between reflectance red edge and chlorophyll content in slash pine. Tree Physiology, 7(1-2-3-4), 33-48. https://doi. org/10.1093/treephys/15.3.203

Çokluk, Ö., Şekercioğlu, G., \& Büyüköztürk, Ş. (2012). Sosyal bilimler için çok değişkenli istatistik: SPSS ve Lisrel uygulamaları. Ankara: Pegem Akademi.

Darvishzadeh, R. (2008). Hyperspectral remote sensing of vegetation parameters using statistical and physical models. (Doctoral dissertation, International Institute for Geo-information Science and Earth Observation (ITC), the Netherlands). Retrieved from https:// research.utwente.nl/en/organisations/faculty-of-geo-informationscience-and-earth-observation

Dash, J., \& Curran, P. J. (2004). The MERIS terrestrial chlorophyll index. Int. J. Remote Sens., 25(23), 5403-5413. https://doi. org $/ 10.1080 / 0143116042000274015$

Datt, B. (1999). Visible/near infrared reflectance and chlorophyll content in eucalyptus leaves. International Journal of Remote Sensing. 20(14), 2741-2759. https://doi.org/10.1080/014311699211778

Demir, E., Saatçioğlu, Ö. ve İmrol, F. (2016). Uluslararası dergilerde yayımlanan eğitim araştırmalarının normallik varsayımları açısından incelenmesi. Current Research in Education, 2(3), 130-148.

Genceli, M. (2007). Tek değişkenli dağılımlar ıçin Kolmogrov-Smirnov, Lilliefors ve Shapiro-Wilk normallik testleri. Sigma Mühendislik ve Fen Bilimleri Dergisi, 25(4), 306-328.

Geng, X. (2013). Modeling cool-season turfgrass lawn growth and quality responses to soil nitrogen and carbon, and tissue nitrogen concentrations. (Doctoral dissertation, University of Connecticut, USA). Retrieved from https://opencommons.uconn.edu/ dissertations $/ 272 /$ ? utm_source=opencommons.uconn. edu $\% 2$ Fdissertations\%2F 272\&utm_medium=PDF\&utm campaign $=$ PDFCoverPages

Gitelson, A. A., Gritz, Y., \& Merzlyak, M. N. (2003). Relationships between leaf chlorophyll content and spectral reflectance and algorithms for non-destructive chlorophyll assessment in higher plant leaves. Journal of Plant Physiology, 160, 271-282. https://doi. org/10.1078/0176-1617-00887

Göksu, G., Karabulut, \& M., Karakoç., A. (2015, Mayıs). Türkiye’de bitki örtüsünün SPOT VEGETATION verileri ile incelenmesi. Coğrafyacılar Derneği Uluslararası Kongresi’nde sunulan bildiri, Ankara Üniversitesi, Ankara.

He, Y., \& Mui, A. (2010). Scaling up semi-arid grassland biochemical content from the leaf to the canopy level: Challenges and opportunities. Sensors, 10, 11072-11087. https://doi.org/10.3390/s101211072

He, Y. (2008). Modeling grassland productivity through remote sensing products. (Doctoral dissertation, University of Saskatchewan, Saskatoon, Canada). Retrieved from https://harvest.usask.ca/ handle/10388/etd-03272008-112659

He, Y., Guo, X., \& Wilmshurst, J. F. (2009). Reflectance measures of grassland biophysical structure. International Journal of Remote Sensing, 30(10), 2509-2521. https://doi.org/10.1080/01431160802552751
Jiang Z., Huete, A., Li., J, \& Chen, Y. (2006). An analysis of anglebased with ratio-based vegetation indices. IEEE Transactions on Geoscience and Remote Sensing, 44(9), 2506-2513. doi: 10.1109/ TGRS.2006.873205

Jin, Y., Yang, X., Qiu, J., Li, J., Gao, T., Wu, Q., Zhao, F., Ma, H., Yu, H., \& Xu, B., (2014). Remote sensing-based biomass estimation and its spatio-temporal variations in temperate grassland, Northern China. Remote Sensing, 6, 1496-1513. https://doi.org/10.3390/ rs6021496

Karabulut, M., 2006. NOAA AVHRR verilerini kullanarak Türkiye'de bitki örtüsünün izlenmesi ve incelenmesi. Coğrafi Bilimler Dergisi, 4(1), 29-42.

Karabulut, M. (2014). Vejetasyon coğrafyası araştırma yöntemleri. Y. Arı, I. Kaya (Ed.), Coğrafyada araştırma yöntemleri kitabı içinde (s. 355-365). Balıkesir: Coğrafyacılar Derneği Yayınları.

Karabulut, M. (2018). An examination of spectral reflectance properties of some wetland plants in Göksu Delta, Turkey. Journal of International Environmental Application and Science, 13(4), 194203.

Karabulut, M., (2019). Vejetasyon çalışmalarında uzaktan algılama. D.D. Yavaşlı, K. Ölgen (Ed.), Coğrafyada uzaktan algılama kitabı içinde (s. 109-160). İstanbul: Kriter Yayınları.

Karakoç, A. (2019). Otlaklardaki biyofiziksel ve biyokimyasal özelliklerin hiperspektral uzaktan algilama verileri ile incelenmesi, (Doktora Tezi). Kahramanmaraş Sütçü İmam Üniversitesi Sosyal Bilimler Enstitüsü, Kahramanmaraş.

Kim, H. Y. (2013). Statistical notes for clinical researchers: Assessing normal distribution (2) using skewness and kurtosis. Restorative Dentistry \& Endodontics, 38(1), 52-54. http://doi.org/10.5395/ rde.2013.38.1.52

Lillesand, T. M., Keifer, R. W., \& Chipman, J. W. (2018). Uzaktan algılama ve görüntü yorumlama. (K.Ş Kavak, Çev.). Ankara: Palme Yayınevi.

Li, Z., Xu, D., \& Guo, X. (2014). Remote sensing of ecosystem health: Opportunities, challenges, and future perspectives. Sensors, 14, 21117-21139. doi:10.3390/s141121117

Ma, B. L., Morrison, M. J., \& Dwyer, L. M. (1996). Canopy light reflectance and field greenness to assess nitrogen fertilization and yield of maize. Agronomy Journal, 88(6), 915-920. https://doi. org/10.2134/agronj1996.00021962003600060011x

Mangiafico, S. S., \& Guillard, K. (2005). Turfgrass reflectance measurements, chlorophyll, and soil nitrate desorbed from anion exchange membranes. Crop Sci., 45, 259-265. https://doi. org/10.2135/cropsci2005.0259

Mcgrew, J. C., Lembo, A. J., \& Monroe, C. B. (2014). An introduction to statistical problem solving in geography. 3rd ed. Long Grove, IL: Waveland Press.

Peddle, D. R., White, H. P., Soffer, R. J., Miller, J. R., \& Ledrew, E. F. (2001). Reflectance processing of remote sensing spectroradiometer data. Computer \& Geoscience, 27, 203-213. https://doi.org/10.1016/ S0098-3004(00)00096-0 
Sims, D. A., \& Gamon, J. A. (2002). Relationships between leaf pigment content and spectral reflectance across a wide range of species, leaf structures and developmental stages. Remote Sens. Environ., 81, 337-354. https://doi.org/10.1016/S0034-4257(02)00010-X

Tong, A., \& He, Y. (2014, July). Remote sensing of grassland chlorophyll content: assessing the spatial-temporal performance of spectral indices. IEEE International Geoscience and Remote Sensing Symposium, Quebec City, Quebec, Canada. Erişim adresi: https:// ieeexplore.ieee.org/document/6947069

Varol, Ö. (2003). Flora of Başkonuş Mountain (Kahramanmaraş). Turkish Journal of Botany, 27(2), 117-139.

Wong, K. K., \& He, Y. (2013). Estimating grassland chlorophyll content using remote sensing data at leaf, canopy, and landscape scales. Canadian Journal of Remote Sensing, 3, 155-166. https://doi. org/10.5589/m13-021

Wu, C., Niu, Z., Tang, Q., \& Huang, W. (2008). Estimating chlorophyll content from hyperspectral vegetation indices: Modeling and validation. Agricultural and Forest Meteorology, 148(8), 12301241. https://doi.org/10.1016/j.agrformet.2008.03.005
Xue, L., Cao, W., Luo, W., Dai, T., \& Zhu, Y. (2004). Monitoring leaf nitrogen status in rice with canopy spectral reflectance, Agron. J., 96(1), 135-142. https://doi.org/10.2134/agronj2004.1350

Yin, C., He, B., Quan, X., \& Liao, Z. (2016). Chlorophyll content estimation in arid grasslands from Landsat-8 OLI data. International Journal of Remote Sensing, 37(3), 615-632. https://doi.org/10.1080 /01431161.2015.1131867

Zarco-Tejada, P. J., Miller, J. R., Noland, T. L., Mohammed, G. H., \& Sampson, P. H. (2001). Scaling-up and model inversion methods with narrowband optical indices for chlorophyll content estimation in closed forest canopies with hyperspectral data. IEEE T. Geosci. Remote, 39(7), 1491-1507. doi: 10.1109/36.934080.

Zhao, F., Xu, B., Yang, X., Jin, Y., Li, J., Xia, L., ..., \& Ma, H. (2014). Remote sensing estimates of grassland aboveground biomass based on MODIS net primary productivity (NPP): A case study in the Xilingol Grassland of Northern China. Remote sensing, 6(6), 53685386. https://doi.org/10.3390/rs6065368 
